\title{
PERBEDAAN PENINGKATAN KEMAMPUAN BERPIKIR KREATIF SISWA YANG DIAJAR DENGAN PEMBELAJARAN OPEN ENDED DAN PBL DI SMA NEGERI 2 KISARAN
}

\author{
Jenny Vera Togatorop ${ }^{1}$, Waminton Rajagukguk ${ }^{2}$ \\ ${ }^{1,2)}$ Mahasiswa dan Dosen Jurusan Matematika FMIPA Unimed Medan \\ email : jenny.togatorop25@gmail.com
}

\begin{abstract}
ABSTRAK
Tujuan dari penelitian ini adalah untuk mengetahui apakah peningkatan kemampuan berpikir kreatif siswa yang diajar dengan pembelajaran Open Ended lebih tinggi dari peningkatan kemampuan berpikir kreatif siswa yang diajar dengan pembelajaran Berbasis Masalah di SMA Negeri 2 Kisaran dan untuk mendeskripsikan proses hasil jawaban siswa. Penelitian ini merupakan penelitian kuasi ekperimen. Populasi dari penelitian adalah seluruh siswa kelas XII SMA Negeri 2 Kisaran .Sampel dari penelitian ini adalah kelas XII-IPA-1 sebagai kelas eksperimen I yang diajar dengan pembelajaran Open Ended (35 siswa) dan XII-IPA-3 sebagai kelas eksperimen II yang diajar dengan pembelajaran Berbasis Masalah (35 siswa). Desain penelitian ini adalah mengunakan desain pretest-posttest. Instrument penelitian ini menggunakan test kemampuan berpikir kreatif siswa. Hasil dari penelitian ini adalah peningkatan kemampuan berpikir kreatif siswa yang diajar dengan pembelajaran Open Ended lebih tinggi dari peningkatan kemampuan berpikir kreatif siswa yang diajar dengan pembelajaran Berbasis Masalah dengan perbedaan rata-rata 6,1428 dan peningkatan indikator paling tinggi pada pembelajaran Open Ended pada indikator kelancaran dan yang paling rendah elaborasi sedangkan indikator peningkatan paling tinggi pada pembelajaran Berbasis Masalah adalah kelancaran dan yang paling rendah adalah orisinalitas.

Kata kunci : Peningkatan Kemampuan Berpikir Kreatif Siswa, Pembelajaran Open Ended, Pembelajaran Berbasis Masalah
\end{abstract}

\section{ABSTRACT}

The aim of this research is to study if the increase ability student's creative thinking that implement Open Ended Learning higher than implement Problem Based Learning and to describe the proses of student's answer.This research is quasi experiment research.The population of this research is all student in class XII SMA Negeri 2 Kisaran. The sample of this research consists of two class, namely, XII-IPA-1 as the first experiment class taught using Open Ended Learning (35 pupils), XII-IPA-3 as the second experiment class taught using Problem Based Learning (35 pupils).This research Design of this research was two-group pretest-posttest design. Ability of student's creative thinking was measured by using test of ability student's creative thinking. The result of this study showed that the increase ability that implement Open Ended Learning 6,1428 higher than implement Problem Based Learning and the highest increase indicator in class taught using Open Ended Learning was fluency and the the lowest was elaboration while highest increase indicator in class taught using Problem Based Learning was fluency and the lowest is original.

Keywords : Increase Ability Student's Creative Thinking, Open Ended Learning, Problem Based Learning

Jenny Vera Togatorop, Waminton Rajagukguk. Perbedaan Peningkatan Kemampuan Berpikir Kreatif Siswa yang Diajar dengan Pembelajaran Open Ended dan PBL di SMA Negeri 2 Kisaran. Jurnal Inspiratif, Vol. 4, No. 1 April 2018. 


\section{PENDAHULUAN}

Pendidikan merupakan hal yang penting dalam membangun peradaban bangsa. Pendidikan adalah aset untuk membangun sumber daya manusia yang berkualitas melalui pendidikan yang bermutu, sehingga bangsa dan negara akan terjunjung tinggi martabatnya dimata dunia. Kemajuan suatu bangsa sangat ditentukan oleh kualitas sumber daya manusia (SDM). Pendidikan memegang peranan penting dalam pembangunan bangsa karena berhasilnya pembangunan di bidang pendidikan akan sangat berpengaruh terhadap pembangunan di bidang lainnya. Sekarang ini, diperlukan pendidikan yang tidak hanya mampu menjadikan peserta didik cerdas dalam teoritical science (teori ilmu), tetapi juga cerdas practical science (praktik ilmu). Oleh karena itu, diperlukan strategi bagaimana pendidikan bisa menjadi sarana untuk membuka pola pikir peserta didik. Ilmu yang mereka pelajari memiliki kebermaknaan untuk hidup sehingga ilmu tersebut mampu merubah sikap, pengetahuan dan keterampilan menjadi lebih baik (Shoimin, 2014:2021)

Matematika adalah mata pelajaran yang diajarkan dari jenjang pendidikan menengah. Selain mempunyai sifat yang abstrak, pemahaman konsep matematika yang baik sangatlah penting karena untuk memahami konsep yang baru diperlukan prasarat pemahaman konsep lainnya. Matematika merupakan ilmu bersifat universal dan terbentuk sebagai hasil olah pikir manusia yang berkaitan dengan ide, proses, dan penalaran (Suherman, 2003). Matematika memiliki peranan penting dalam kehidupan. Sehingga sangat perlu untuk belajar matematika. Ada lima alasan perlunya belajar matematika yaitu (1) matematika merupakan sarana berpikir yang jelas dan logis, (2) sarana untuk memecahkan masalah kehidupan sehari-hari, (3) sarana mengenal pola-pola hubungan dan generalisasi pengalaman, (4) sarana untuk mengembangkan kreativitas, dan (5) sarana untuk meningkatkan kesadaran terhadap perkembangan budaya (Cornelius dalam Abdurahman 2009). Namun sangat banyak orang yang memandang matematika sebagai bidang studi yang paling sulit, tetapi semua orang harus mempelajarinya karena selalu digunakan dalam segala segi kehidupan; semua bidang studi memerlukan ketrampilan matematika yang sesuai; merupakan sarana komunikasi yang kuat, singkat,dan jelas; dapat digunakan untuk menyajikan informasi dalam berbagai cara; meningkatkan kemampuan berpikir logis, ketelitian, dan kesadaran keruangan; dan memberikan kepuasan terhadap usaha memecahkan masalah yang menantang (Cockroft, dalam Abdurahman 2009).

Yang menjadi masalah, kreativitas menjadi topik yang sering terabaikan dalam pengajaran matematika. Pada umumnya orang beranggapan bahwa kreativitas tidak memiliki kaitan dengan matematika. Menurut Pehnoken (dalam Mahmudin, 2010) kreativitas tidak hanya terjadi pada bidang-bidang tertentu, seperti seni,sastra, atau sains, melainkan juga

Jenny Vera Togatorop, Waminton Rajagukguk. Perbedaan Peningkatan Kemampuan Berpikir Kreatif Siswa yang Diajar dengan Pembelajaran Open Ended dan PBL di SMA Negeri 2 Kisaran. Jurnal Inspiratif, Vol. 4, No. 1 April 2018. 
ditemukan dalam berbagai bidang kehidupan termasuk matematika. Pembahasan mengenai kreativitas dalam matematika lebih ditekankan pada prosesnya, yakni proses berpikir kreatif. Pada dasarnya pembelajaran matematika perlu dirancang sedemikian sehingga berpotensi dalam mengembangkan kemampuan berpikir kreatif siswa. Pengembagan kemampuan berpikir kreatif dilakukan seiring dengan pengembangan cara mengevaluasi.

Pentingnya kreativitas dalam matematika dikemukakan oleh Bishop (dalam Mahmudi, 2010) yang menyatakan bahwa seseorang memerlukan dua keterampilan berpikir matematis, yaitu berpikir kreatif yang sering diidentikkan dengan intuisi dan kemampuan berpikir analitik yang diidentikkan dengan kemampuan berpikir logis. Sedangkan menurut Livne ( dalam Mahmudi, 2010) berpikir kreatif merujuk pada kemampuan untuk menghasilkan solusi bervariasi yang bersifat baru terhadap masalah matematika yang bersifat terbuka. Dalam kegiatan pembelajaran, siswa yang memiliki kemampuan berpikir kreatif dapat membantu siswa lain yang mengalami masalah dalam pembelajaran. Namun sejauh ini kemampuan berpikir kreatif siswa masih memprihatinkan. Terlihat dari hasil uji PISA tahun 2006 menunjukkan prestasi literasi matematika Indonesia berada pada peringkat ke 50 dari 57 negara. Siswa Indonesia beradapa pada peringkat 10 besar terbawah di antara negara-negara partisipan PISA.

Rendahnya kemampuan berpikir kreatif siswa dalam pelajaran matematika disebabkan karena model pembelajaran yang digunakan oleh guru kurang melibatkan aspek keterampilan sains. Model pembelajaran yang biasa dilakukan di sekolah tersebut adalah model pembelajaran konvensional. Model pembelajaran konvensional adalah model pembelajaran yang lazim diterapkan dalam pembelajaran seharihari dan sudah terbiasa dilakukan di kelas, sifatnya berpusat pada guru (teacher centered learning) dan kurang memperhatikan keseluruhan situasi belajar serta guru jarang memanfaatkan teknologi yang ada di sekolah. Selama proses pembelajaran matematika dikelas, metode yang dominan digunakan guru adalah ceramah, tanya jawab, penugasan dan siswa diarahkan untuk menghapal informasi serta rumusrumus. Jarang sekali siswa dihadapkan masalah-masalah yang kontekstual. Pembelajaran matematika yang sering terjadi di sekolah menekankan pengerjaan soal-soal yang bersifat hitungan yang identik dengan rumusrumus. Selain itu, siswa jarang sekali dihadapkan pada suatu masalah. Padahal, yang dipelajari dalam matematika adalah masalah yang sering dilihat bahkan dialami siswa dalam kehidupan sehari-hari. Pembelajaran yang sama ditemukan di SMA N 2 KISARAN dan peneliti melakukan observasi untuk melihat tingkat kemampuan berpikir kreatif siswa. Setelah peneliti memberikan tes dengan satu masalah kepada siswa untuk melihat tingkat kemampuan berpikir kreatif siswa. Dengan penilaian berdasarkan pedoman pengukuran kemampuan berpikir kreatif yang dirancang oleh peneliti diperoleh kemampuan berpikir kreatif siswa rendah.

Dari data yang diperoleh bahwa hanya 1 siswa atau 2,778\% siswa yang memperoleh nilai pada interval

Jenny Vera Togatorop, Waminton Rajagukguk. Perbedaan Peningkatan Kemampuan Berpikir Kreatif Siswa yang Diajar dengan Pembelajaran Open Ended dan PBL di SMA Negeri 2 Kisaran. Jurnal Inspiratif, Vol. 4, No. 1 April 2018. 
cukup, ada 3 siswa atau $8.33 \%$ siswa yang memperoleh nilai pada interval rendah bahkan ada 32 siswa atau $88,89 \%$ siswa yang memperoleh nilai pada interval sangat rendah sehingga disimpulkan bahwa nilai kemampuan berpikir kreatif siswa masih sangat rendah. Dari jawaban yang dibuat oleh siswa dilihat dari aspek kelancaran, keluwesan, keaslian dan elaborasi jawaban sangat rendah. Karena siswa hanya mampu membuat satu cara penyelesaian dan tidak semua siswa dapat menjawab dengan benar.

Jawaban yang mereka sajikan memang ada pada bagian-bagian tertentu yang benar seperti pada bagian (a) yang menjawab semua benar, akan tetapi tidak untuk bagian (b) dan (c) . Hal ini menunjukkan kemampuan berpikir kreatif siswa tersebut masih sangat rendah baik dari segi kelancaran, keluwesan, kebaruan dan keaslian.

Rendahnya berpikir kreatif siswa dapat disebabkan oleh beberapa faktor, yaitu: pemberian evaluasi dan hadiah yang kurang tepat, penekanan pada kompetisi, lingkungan yang membatasi da siswa tidak bebas untuk memilih (Munandar, 2009:234) pemahaman konsep yang tidak matang dan juga cara mengajar yang kurang tepat. Guru matematika yang diobservasi mengaajar dengan model pembelajaran konvensional yang terlalu menekankan penguasaan sejumlah konsep tana mengkomunikasikan cara berpikir kreatif untuk menguasai konsep tersebut, kurang meibatkan interaksi guru dengan siswa maupun atar siswa dalam kelas matematika. Jadi mengajar hanya sebatas transfer ilmu daru guru kepada siswa. Akibatnya, siswa bersifat pasif dan mendapatkan konsep tetapi tidak memahami apalagi mengembangkannya dan menghubungkannya dengan masalah-masalah sehari-hari yang muncul.Dimana pembelajaran tersebut lebih menekankan pada menghapal konsep dan prosedur matematika guna menyelesaikan soal. Pengajaran yang hanya beroireintasi pada hasil belajar yang dapat diamati dan diukur ( pandangan behavioristik) yang cenderung pada penguasaan pengetahuan itu merupakan akumulasi pengetahuan sebelumnya. Pemberian informasi sebanyak-banyaknya kepada siswa tanpa mempertimbangkan kebermaknaannya, bagaikan tumpukan pengetahuan dimana konsep-konsep dan prinsip-prinsip matematika yang ada pada struktur kognitif siswa terkessan saling terisolasi. Akibatnya, siswa tidak dapat menerapkan konsep dan prinsip matematika dalam pemecahan masalah dan sukar untuk mengadaptasikan pengetahuannya terhadap perubahan lingkungannya , karena mereka tidak mengalami penemuan konsep dan prinsip tersebut". Surya, dkk. (2013) menemukan bahwa kesulitan yang diperoleh siswa adalah pada saat memahami, menggambar diagram, membaca grafik dengan benar, pemahaman konsep matematika formal, dan penyelesaian masalah matematika. Temuan ini juga relevan dengan Novriani, dan Surya (2017).

Peneliti juga melalukan wawancara singkat dengan salah seorang guru bidang matematika (Siahaan, 27 Oktober 2017 ) yang mengatakan bahwa :

"Siswa mengalami kesulitan dalam menyelesaikan permasalahan matematika yang membutuhkan penalaran dan pemahaman. Jika soal yang diberikan diubah sedikit saja , siswa kesulitan mengerjakannya. Hal ini disebabkan oleh kemampuan berpikir kreatif siswa yang masih kurang. Siswa tidak bisa menghubungkan konsepkonsep yang sudah dipelajarinya. Selain itu, metode mengajar yang digunakan guru kurang tepat dan juga pengaruh lingkungan sehingga siswa cepat merasa

Jenny Vera Togatorop, Waminton Rajagukguk. Perbedaan Peningkatan Kemampuan Berpikir Kreatif Siswa yang Diajar dengan Pembelajaran Open Ended dan PBL di SMA Negeri 2 Kisaran. Jurnal Inspiratif, Vol. 4, No. 1 April 2018. 
hebat jika mampu mengerjakan beberapa soal sehingga tidak tertarik untuk memecahkan masalah yang relatif berbeda dengan yang biasa dipecahkannya".

dengan masalah di atas dapat diatasi pembelajaran yang tidak kaku melainkan memberikan kesempatan bagi para siswa membangun sendiri ilmu maupun konsep dengan cara mereka sendiri serta mengaitkannya dengan informasi-informasi yang sudah diperolehnya sebelumnya dan juga permasalahan yang dihadapinya seharihari.Dalam Peraturan Pemerintah Nomor 17 Tahun 2010 tentang Pengolahan dan Penyelenggaraan Pendidikan bertujuan untuk membangun landasan bagi berkembangnya potensi peserta didik, salah satunya agar menjadi manusia yang berilmu, cakap, kritis, kreatif, dan inovatif. Berpikir kreatif dalam hal ini adalah kemampuan siswa untuk menciptakan gagasangagasan baru dengan melihat hubungan antara unsur-unsur yang sudah ada sebelumnya dengan melihat kemampuan berpikir kreatif siswa pada perilaku kreatif yaitu (1) kelancaran (fluency), (2) keluwesan (flexibility), (3) elaborasi (elaboration), (4) keaslian (originality). Salah satu upaya untuk mengetahui kemampuan berpikir kreatif siswa adalah dengan desain proses pembelajaran dalam kelas yaitu dengan model pembelajaran yang tepat. Model pembelajaran yang tepat akan menjadikan suasana belajar yang menyenangkan dan membuat siswa tidak bosan dengan pembelajaran sehingga tujuan pembelajaran dapat tercapai .Model pembelajaran yang sesuai dengan kriteria tersebut adalah pembelajaran Open Ended dan pembelajaran Berbasis Masalah.

Secara teori , kedua pembelajaran tersebut mampu meningkatkan kemampuan berpikir kreatif siswa ke tingkat yang lebih tinggi. Menurut Shimada dan Becker (dalam Afgani, 2010 :3) munculnya pendekatan Open Ended berawal dari pandangan bagaimana menilai siswa secara objektif kemampuan berpikir tingkat tinggi matematika. Seperti yang diketahui bahwa dalam pembelajaran matematika, rangkaian pengetahuan, ketrampilan, konsep-konsep, prinsipprinsip atau aturan-aturan yang biasanya diberikan kepada siswa dalam langkah sistematis. Pembelajaran open ended memberi kesempatan kepada siswa untuk memperoleh pengetahuan, pengelamanan menemukan, mengenali, memecahkan masalah dengan beberapa teknik berpikir sehingga cara berpikir siswa terlatih dengan baik. Pembelajaran open ended mendorong siswa mengembangkan ide-ide kreatif dan pola pikir matematis dengan memanfaatkan konsep matematika, sehingga diharapkan siswa memiliki kemampuan pemecahan masalah matematis dan berpikir kreatif. Sedangkan pembelajaran berbasis masalah bermanfaat dalam membantu siswa mengembangkan ketrampilan pemecahan masalah. Banyak penelitian membenarkan bahwa pembelajaran berbasis masalah adalah sebuah pendekatan yang efektif dalam meningkatkan kemampuan berpikir kreatif. Sebagai contoh adalah laporan Bootge,Grant,et all (dalam jurnal Min Liu,et all) yang menyatakan bahwa siswa yang diajari dengan metode pembelajaran berbasis masalah mendapat pencapaian yang lebih baik

Jenny Vera Togatorop, Waminton Rajagukguk. Perbedaan Peningkatan Kemampuan Berpikir Kreatif Siswa yang Diajar dengan Pembelajaran Open Ended dan PBL di SMA Negeri 2 Kisaran. Jurnal Inspiratif, Vol. 4, No. 1 April 2018. 
dibandingkan dengan siswa yang diajari dengan metode tradisonal .

\section{METODE PENELITIAN}

Penelitian ini dilakukan
dengan menggunakan metode ekspeimen dengan rancangan two groups pretest-posttest design. Model pembelajaran yang digunakan adalah model pembelajaran Open Ended dan model pembelajaran Berbasis Masalah.

Sampel penelitian terdiri dari dua kelas yang mewakili populasi dengan mempunyai karakteristik yang sama yaitu kelas XII-IPA-1 dan XII-
IPA-3 yang kelas pertama dijadikan kelas ekperimen I dan kelas kedua dijadikan kelas eksperimen II. Pengambilan sampel dan penentuan kelas sampel dalam penelitian diambil secara acak yaitu dengan menggunakan cluster random sampling. Kelas XIIIPA-1 sebagai kelas eksperimen I yang diajarkan dengan menggunakan model pembelajaran Open Ended dan kelas XII-IPA-3 sebagai kelas eksperimen yang diajarkan dengan menggunakan model pembelajaran berbasis masalah.

Pengujian hipotesis dilakukan dengan menggunakan uji-t untuk sampel yang independen.

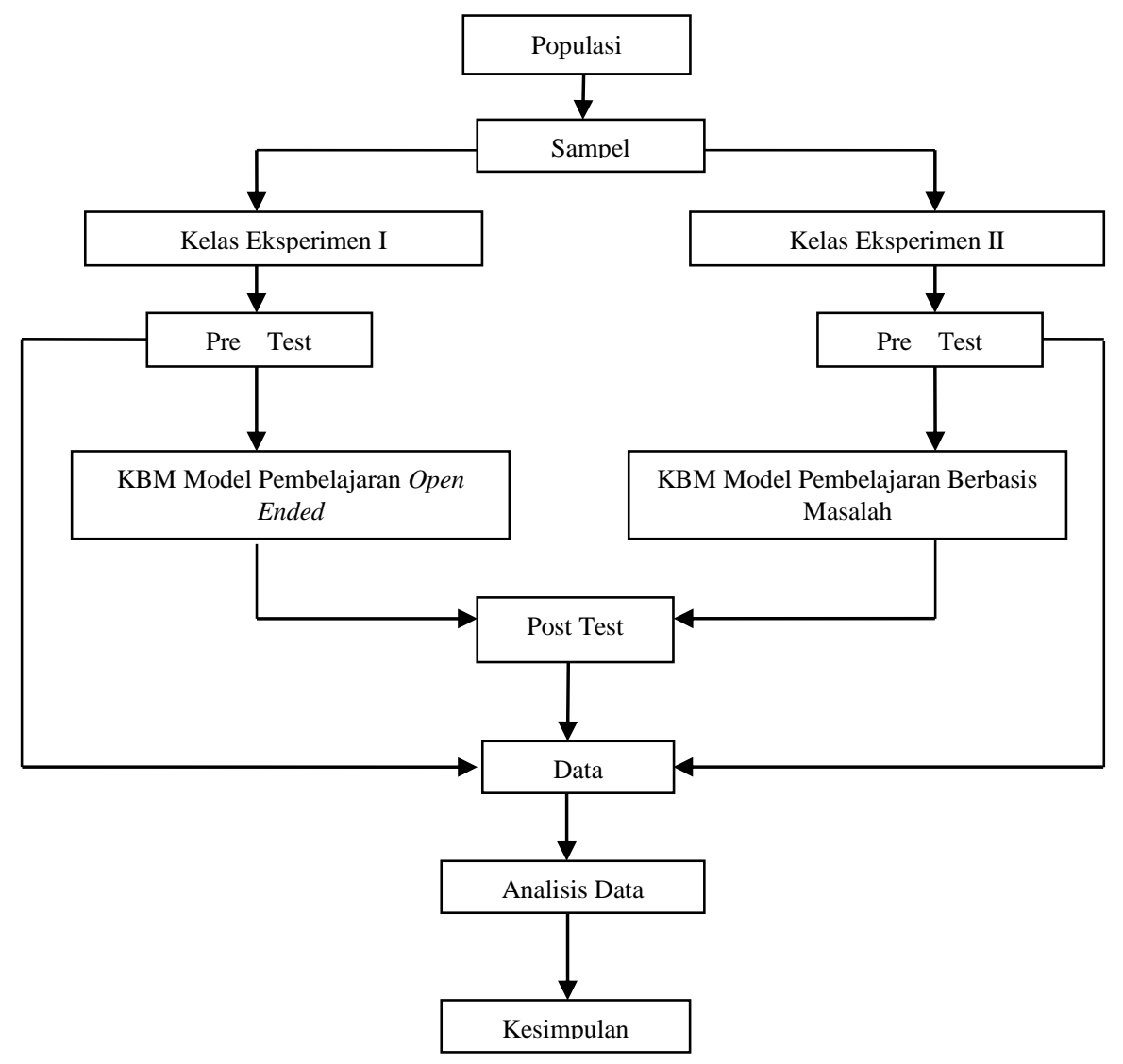

Gambar 1. Bagan Prosedur Penelitian

\section{HASIL PENELITIAN DAN \\ PEMBAHASAN}

1. Deskripsi Hasil Penelitian

Jenny Vera Togatorop, Waminton Rajagukguk. Perbedaan Peningkatan Kemampuan Berpikir Kreatif Siswa yang Diajar dengan Pembelajaran Open Ended dan PBL di SMA Negeri 2 Kisaran. Jurnal Inspiratif, Vol. 4, No. 1 April 2018. 
Penelitian ini dilakukan di kelas XII SMA Negeri 2 Kisaran,dengan menerapkan model pembelajaran Open Ended pada kelas ekperimen I dan

model pembelajaran Berbasis Masalah pada kelas eksperimen II. Dalam penelitian ini, data yang diolah adalah selisih antara nilai pre-test dan post-test siswa. Pengolahan data secara terperinci tidak disajikan, namun secara lengkapnya data-data telah diolah dan dapat dilihat pada lampiran. Data yang diperoleh pada penelitian setelah ditabulasi diperoleh deskripsi data masing-masing variabel sebagai berikut:

\section{Statistika Deskripsi Hasil Penelitian}

\section{a. Kelas Eksperimen I}

Berdasarkan penelitian yang telah dilakukan pada kelas ekperimen I yang menerapkan model pembelajaran Open Ended, diperoleh data hasil penelitian bahwa selisih posttest-pretest tertinggi adalah 40 sedangkan selisih posttest-pretest terendah adalah 4 dengan nilai rata-rata selisih post-testpretest kemampuan berpikir kreatif siswa adalah 21,029 dengan simpangan baku 9,224.

Sedangkan kriteria tingkat kemampuan berpikir kreatif siswa sebelum dan sesudah diadakan perlakuan disajikan dalam tabel berikut.

Tabel 1 Kriteria Tingkat Kemampuan Berpikir Kreatif Siswa di Kelas Eksperimen I

\begin{tabular}{|l|l|l|l|}
\hline \multirow{2}{*}{$\begin{array}{l}\text { Rentang } \\
\text { Nilai }\end{array}$} & \multirow{3}{*}{ Kriteria } & \multicolumn{3}{|l|}{ Jumlah Siswa } \\
\cline { 3 - 4 } & & $\begin{array}{l}\text { Pre } \\
\text { Test }\end{array}$ & $\begin{array}{l}\text { Post } \\
\text { Test }\end{array}$ \\
\hline $90-100$ & Sangat & 0 & 3 \\
\hline
\end{tabular}

\begin{tabular}{|l|l|l|l|}
\hline & Tinggi & & \\
\hline $80-89$ & Tinggi & 0 & 4 \\
\hline $65-79$ & Cukup & 0 & 10 \\
\hline $55-64$ & Rendah & 4 & 9 \\
\hline $0-54$ & $\begin{array}{l}\text { Sangat } \\
\text { Rendah }\end{array}$ & 31 & 9 \\
\hline
\end{tabular}

Dari tabel di atas dapat dilihat bahwa terdapat perbedaan hasil sesudah diadakannya perlakuan. Terdapat 3 siswa yang sudah mencapai kriteria sangat tinggi, 4 siswa yang mencapai kriteria tinggi, 10 siswa berada pada kriteria cukup, 9 siswa berada pada kriteria rendah sedangkan untuk kriteria sangat rendah berkurang dari 31 siswa menjadi 9 siswa. Dari sini dapat disimpulkann bahwa sesudah menerapkan model pembelajaran Open Ended terdapat 17 siswa sudah mencapai ketuntasan minimum.

\section{b. Kelas Eksperimen II}

Berdasarkan penelitian yang telah dilakukan pada kelas ekperimen II yang menerapkan model pembelajaran Berbasis Masalah, diperoleh data hasil penelitian bahwa selisih posttest-pretest tertinggi adalah 28 sedangkan selisih posttest-pretest terendah adalah 1 dengan nilai rata-rata selisih post-testpretest kemampuan berpikir kreatif siswa adalah 14,886 dengan simpangan baku 8,584.

Sedangkan kriteria tingkat kemampuan berpikir kreatif siswa sebelum dan sesudah diadakan perlakuan disajikan dalam tabel berikut.

Tabel 2 Kriteria Tingkat Kemampuan Berpikir Kreatif Siswa di KelasEksperimen II

\begin{tabular}{|l|l|l|l|}
\hline \multirow{2}{*}{$\begin{array}{l}\text { Rentang } \\
\text { Nilai }\end{array}$} & \multirow{3}{*}{ Kriteria } & \multicolumn{2}{|l|}{ Jumlah Siswa } \\
\cline { 3 - 4 } & & Pre & Post \\
& Test & Test \\
\hline
\end{tabular}

Jenny Vera Togatorop, Waminton Rajagukguk. Perbedaan Peningkatan Kemampuan Berpikir Kreatif Siswa yang Diajar dengan Pembelajaran Open Ended dan PBL di SMA Negeri 2 Kisaran. Jurnal Inspiratif, Vol. 4, No. 1 April 2018. 


\begin{tabular}{|l|l|l|l|}
\hline $90-100$ & $\begin{array}{l}\text { Sangat } \\
\text { Tinggi }\end{array}$ & 0 & 0 \\
\hline $80-89$ & Tinggi & 0 & 4 \\
\hline $65-79$ & Cukup & 0 & 6 \\
\hline $55-64$ & Rendah & 8 & 14 \\
\hline $0-54$ & $\begin{array}{l}\text { Sangat } \\
\text { Rendah }\end{array}$ & 27 & 11 \\
\hline
\end{tabular}

Dari tabel di atas dapat dilihat bahwa terdapat perbedaan hasil sesudah diadakannya perlakuan. Tidak terdapat siswa yang sudah mencapai kriteria sangat tinggi, 4 siswa yang mencapai kriteria tinggi, 6 siswa berada pada kriteria cukup, 14 siswa berada pada kriteria rendah sedangkan untuk kriteria sangat rendah berkurang dari 27 siswa menjadi 11 siswa. Dari sini dapat disimpulkann bahwa sesudah menerapkan model pembelajaran Berbasis Masalah terdapat 10 siswa sudah mencapai ketuntasan minimum.

Berikut ini adalah diagram batang test kemampuan berpikir kreatif siswa yang diperoleh setelah perlakuan:

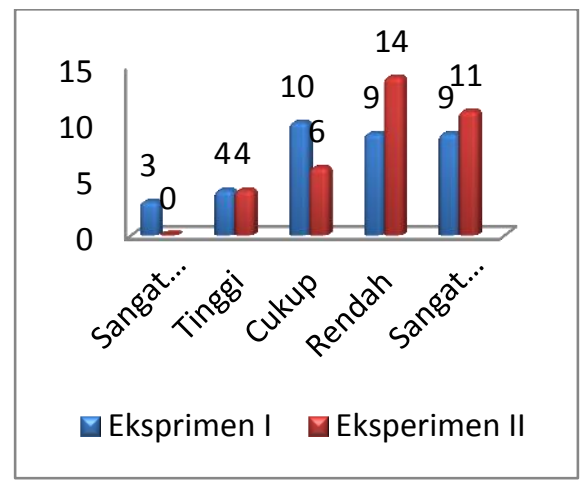

Gambar 2 Kriteria Tingkat

\section{Kemampuan Berpikir Kreatif Siswa}

Dari gambar di atas dapat dilihat bahwa berdasarkan kriteria ketuntasan minimal (KKM) yang ditetapkan oleh sekolah, pada kelas ekperimen I yang diterapkan model pembelajaran Open Ended diperoleh 7 dari 35 siswa atau $20 \%$ siswa telah mencapai nilai KKM dan 28 dari 35 siswa atau $80 \%$ yang belum mencapai nilai KKM. Sedangkan pada kelas ekperimen II yang diterapkan model pembelajaran Berbasis Masalah diperoleh 4 dari 35 siswa atau $11,42 \%$ siswa telah mencapai nilai KKM dan 31 dari 35 siswa atau $88,58 \%$ yang belum mencapai nilai KKM. Berdasarkan nilai rata-rata siswa di kelas eksperimen I yaitu 67,37 terdapat 15 dari 35 siswa atau $482,85 \%$ siswa mencapai nilai di atas rata-rata dan pada kelas eksperimen II dengan rata-rata 64,48 terdapat 10 dari 35 siswa atau 28,57 \% siswa yang mencapai nilai di atas rata-rata.

\section{Analisis Hasil Penelitian}

Uji normalitas data dilakukan dengan menggunakan uji Liliefors dengan tujuan untuk mengetahui apakah data yang digunakan berdistribusi normal atau tidak. Jika $L_{0}<L_{\text {tabel }}$ maka data berdistribusi normal dan jika $L_{0}>L_{\text {tabel }}$ maka data tidak berdistribusi normal. Nilai $\boldsymbol{L}_{\text {tabel }(\boldsymbol{\alpha}=\mathbf{0 , 0 5})}$ yang digunakan adalah 0,14976 . Walaupun data yang diolah adalah data selisih posttest-pretest siswa, namun peneliti juga melakukan uji normalitas pada data pretest dan posttest siswa. Hasil uji normalitas data selisih posttest-pretest siswa, data pretest dan data posttest siswa dapat dilihat pada tabel berikut :

Tabel 3 Hasil Uji Normalitas Data Pretest Siswa

\begin{tabular}{|l|l|c|c|l|}
\hline Banyak Data & Kelas & $\boldsymbol{L}_{0}$ & $\boldsymbol{L}_{\text {tabel }(\alpha=0,05)}$ & Kesimpulan \\
\hline \hline
\end{tabular}

Jenny Vera Togatorop, Waminton Rajagukguk. Perbedaan Peningkatan Kemampuan Berpikir Kreatif Siswa yang Diajar dengan Pembelajaran Open Ended dan PBL di SMA Negeri 2 Kisaran. Jurnal Inspiratif, Vol. 4, No. 1 April 2018. 


\begin{tabular}{|l|l|l|l|l|}
\hline 35 & Eksperimen I & 0,14084 & 0,14976 & Normal \\
\hline 35 & Eksperimen II & 0,11384 & 0,14976 & Normal \\
\hline
\end{tabular}

Tabel 4 Hasil Uji Normalitas Data Posttest Siswa

\begin{tabular}{|l|l|c|l|l|}
\hline Banyak Data & Kelas & $\boldsymbol{L}_{\mathbf{0}}$ & $\boldsymbol{L}_{\text {tabel }(\boldsymbol{\alpha}=\mathbf{0 , 0 5})}$ & Kesimpulan \\
\hline 35 & Eksperimen I & 0,1352 & 0,14976 & Normal \\
\hline 35 & Eksperimen II & 0,1194 & 0,14976 & Normal \\
\hline
\end{tabular}

Tabel 5 Hasil Uji Normalitas Data Selisih Posttest-Pretest Siswa

\begin{tabular}{|l|l|l|l|l|}
\hline Banyak Data & Kelas & \multicolumn{1}{c|}{$\boldsymbol{L}_{\mathbf{0}}$} & $\boldsymbol{L}_{\text {tabel }(\boldsymbol{\alpha}=\mathbf{0 , 0 5})}$ & Kesimpulan \\
\hline 35 & Eksperimen I & 0,1198 & 0,14976 & Normal \\
\hline 35 & Eksperimen II & 0,1066 & 0,14976 & Normal \\
\hline
\end{tabular}

Dari tabel tersebut menunjukkan $\quad F_{\text {tab 0,05(34,34) }}=1,776$.Jika $\quad F_{\text {hit }}<$

bahwa data tes kemampuan berpikir $\quad F_{t a b \alpha\left(v_{1}, v_{2}\right)}$ maka data homogen dan kreatif siswa kedua kelompok sampel jika $F_{h i t}>F_{\text {tab } \alpha\left(v_{1}, v_{2}\right)}$ maka data tidak dinyatakan berdistribusi normal. homogen. Walaupun data yang diolah

Pengujian homogenitas data adalah data selisih posttest-pretest siswa, dilakukan untuk mengetahui apakah namun peneliti juga melakukan uji kelompok sampel yang digunakan dalam homogenitas pada data pretest dan penelitian ini berasal dari populasi yang posttest siswa. Hasil uji homogenitas homogen atau tidak, artinya apakah data selisih posttest-pretest siswa ,data sampel yang digunakan dapat mewakili pretest dan data posttest siswa dapat seluruh populasi yang ada. Uji yang digunakan dalam penelitian ini adalah dilihat pada tabel berikut :

uji $\quad F$ dengan nilai $F_{t a b \alpha\left(v_{1}, v_{2}\right)}=$

Tabel 6 Hasil Uji Homogenitas Data Pretest Siswa

\begin{tabular}{|l|l|l|l|l|}
\hline Kelas & Varians & $\boldsymbol{F}_{\text {hitung }}$ & $\boldsymbol{F}_{\text {tabel }(\boldsymbol{\alpha}=\mathbf{0 , 0 5})}$ & Kesimpulan \\
\hline Eksperimen I & 29,291 & 1,312 & 1,776 & Homogen \\
\hline Eksperimen II & 38,424 & & & \\
\hline
\end{tabular}

Tabel 7 Hasil Uji Homogenitas Data Posttest Siswa

\begin{tabular}{|l|l|l|l|l|}
\hline Kelas & Varians & $\boldsymbol{F}_{\text {hitung }}$ & $\boldsymbol{F}_{\text {tabel }(\boldsymbol{\alpha}=\mathbf{0 , 0 5})}$ & Kesimpulan \\
\cline { 1 - 5 } Eksperimen I & 183,887 & \multirow{2}{*}{1,004} & 1,776 & Homogen \\
\cline { 1 - 4 } Eksperimen II & 183,067 & & & \\
\hline
\end{tabular}

Tabel 8 Hasil Uji Homogenitas Data Selisih Posttest-Pretest Siswa

\begin{tabular}{|l|l|l|l|l|}
\hline Kelas & Varians & $\boldsymbol{F}_{\text {hitung }}$ & $\boldsymbol{F}_{\text {tabel }(\boldsymbol{\alpha}=\mathbf{0 , 0 5})}$ & Kesimpulan \\
\cline { 1 - 2 } Eksperimen I & 85,087 & \multirow{2}{*}{1,154} & 1,776 & Homogen \\
\cline { 1 - 2 } Eksperimen II & 73,692 & & & \\
\hline
\end{tabular}

Dari tabel tersebut menunjukkan

bahwa data tes kemampuan berpikir

Jenny Vera Togatorop, Waminton Rajagukguk. Perbedaan Peningkatan Kemampuan Berpikir Kreatif Siswa yang Diajar dengan Pembelajaran Open Ended dan PBL di SMA Negeri 2 Kisaran. Jurnal Inspiratif, Vol. 4, No. 1 April 2018. 
kreatif siswa kedua kelompok sampel dinyatakan memiliki varians yang sama atau homogen.

Setelah dilakukan uji normalitas dan uji homogenitas diketahui bahwa sampel dalam penelitian ini adalah sampel yang berdistribusi normal dan homogen maka dilakukan pengujian hipotesis menggunakan uji-t. Dengan kriteria pengujian adalah terima $\mathrm{H}_{0}$ jika $-t_{\frac{1}{2} \alpha}<t<t_{\frac{1}{2} \alpha}$ dimana $t_{\alpha}$ didapat dari daftar distribusi $\mathrm{t}$ dengan $\mathrm{dk}=n_{1}+$

Tabel 9 Hasil Uji Hipotesis Data Selisih Posttest-Pretest Siswa

\begin{tabular}{|l|l|l|l|l|}
\hline Kelas & Nilai Rata-rata & $\boldsymbol{t}_{\text {hitung }}$ & $\boldsymbol{t}_{\text {tabel }\left(\frac{1}{2} \boldsymbol{\alpha}=\mathbf{0 , 0 2 5}\right)}$ & Kesimpulan \\
\hline Eksperimen I & 21,028 & 2,9168 & 1,6676 & Terima $H_{a}$ \\
\hline Eksperimen II & 14,885 & & & \\
\hline
\end{tabular}

Berdasarkan tabel di atas hasil pengujian dengan taraf signifikan $\alpha=0,05 \quad$ dan $\quad d k=n_{1}+n_{2}-2=$ $35+35-2=68$ dengan $t_{\text {hitung }}=$ 2,9168 dan $t_{\text {tabel }}=1,6676$ sehingga terlihat bahwa $t_{\text {hitung }}$ tidak memenuhi pada $-t_{\text {tabel }}<t_{\text {hitung }}<t_{\text {tabel }}$ yang berarti $H_{0}$ ditolak dan $H_{a}$ diterima. Sehingga disimpulkan bahwa kemampuan berpikir kreatif siswa yang diajar dengan pembelajaran Open Ended lebih tinggi dari kemampuan berpikir kreatif siswa yang diajar dengan pembelajaran Berbasis Masalah di SMA Negeri 2 KisaranT.A 2017/2018 dengan perbedaan rata-rata 6,1428 lebih tinggi.

\section{Deskripsi Proses Hasil Jawaban Siswa}

Lembar jawaban posttest siswa dari kelas eksperimen I yang diajar dengan menggunakan model pembelajaran Open Ended dan kelas eksperimen II yang diajar dengan menggunakan model pembelajaran $n_{2}-2$ dan $\alpha=0,05$. Untuk harga $\mathrm{t}$ lainnya $\mathrm{H}_{0}$ ditolak dan $\mathrm{H}_{\mathrm{a}}$ diterima. Setelah diberikan perlakuan maka diperoleh rata-rata selisih PosttestPretest kelas eksperimen I adalah 21,028 dan rata-rata selisih Posttest-Pretest kelas eksperimen II adalah 14,885. Perhitungan uji hipotesis kelas eksperimen I dan kelas eksperimen II secara ringkas ditunjukkan pada tabel berikut:
Berbasis Masalah dideskripsikan dan dianalisis terhadap proses hasil jawaban siswa yang disesuaikan dengan indikator kemampuan berpikir kreatif siswa. Indikator kemampuan berpikir kreatif siswa yang digunakan dalam penelitian ini adalah kelancaran,keluwesan,orisinal dan elaborasi.

\section{a. Deskripsi Proses Hasil Jawaban Pretest Kemampuan Berpikir Kreatif Siswa}

Berdasarkan proses hasil jawaban pretest kemampuan berpikir kreatif dari masing-masing kelas eksperimen maka dapat ditemukan gambaran umum dalam proses hasil jawaban siswa. Berikut akan diuraikan gambaran umum proses hasil jawaban pretest siswa :

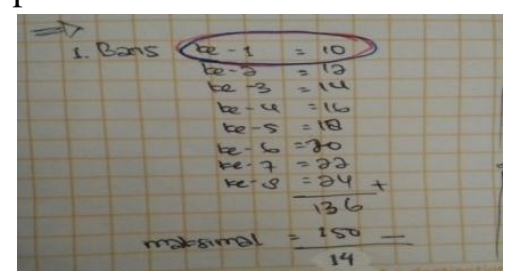

Jenny Vera Togatorop, Waminton Rajagukguk. Perbedaan Peningkatan Kemampuan Berpikir Kreatif Siswa yang Diajar dengan Pembelajaran Open Ended dan PBL di SMA Negeri 2 Kisaran. Jurnal Inspiratif, Vol. 4, No. 1 April 2018. 


\section{Gambar 3 Hasil Jawaban Pretest Siswa}

Gambar 3 merupakan salah satu contoh dari proses hasil jawaban siswa yang masih belum teliti dalam memahami apa yang diketahui dari soal yang diberikan. Pada soal yang diberikan banyak kursi pada baris pertama adalah 12, namun masih ada siswa yang belum teliti dalam membaca soal.

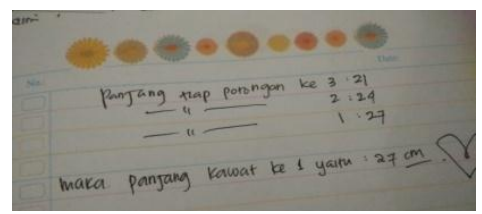

\section{Gambar 4 Hasil Jawaban Pretest Siswa}

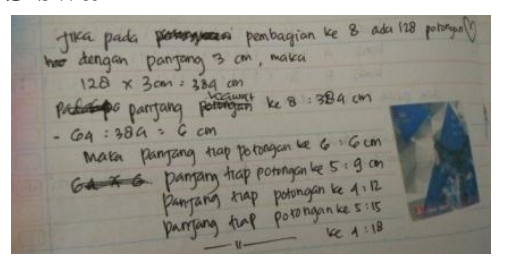

Gambar 5 Hasil Jawaban Pretest Siswa

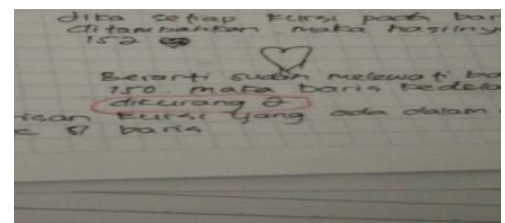

Gambar 6 Hasil Jawaban Pretest Siswa

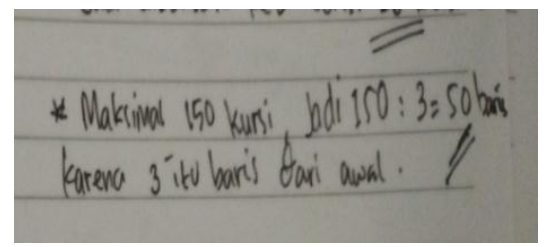

\section{Gambar 7 Hasil Jawaban Pretest Siswa}

Gambar 4,gambar 5, gambar 6 dan gambar 7 merupakan beberapa contoh dari proses hasil jawaban siswa yang masih belum memahami dengan benar apa yang dimaksud dalam soal sehingga cara yang disajikan dan alasan yang diberikan tidak benar. Seperti proses hasil jawaban siswa pada gambar 4 dan gambar 5 salah karena yang dimaksudkan pada soal adalah jika banyak kursi tiap baris mengikuti pola yang diberikan, maka berapa banyak kursi yang mungkin jika kapasitas maksimum kursi dalam gedung adalah 150 .

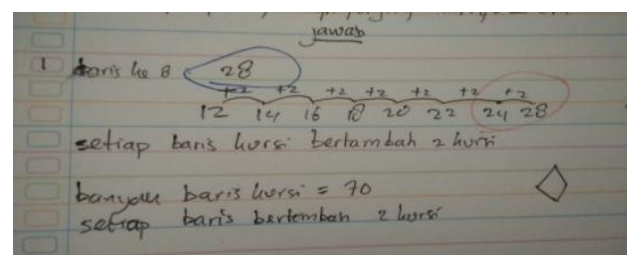

Gambar 8 Hasil Jawaban Pretest Siwa

Gambar 8 merupakan contoh proses hasil jawaban siswa yang sudah teliti dalam mengetahui apa yang dimaksud dalam soal dan sudah tepat dalam memahami apa maksud soal serta menggunakan cara yang tepat namun salah dalam melakukan perhitungan di akhir. Seharusnya jawaban yang diperoleh ada 26 namun yang dituliskan oleh siswa adalah 28 .

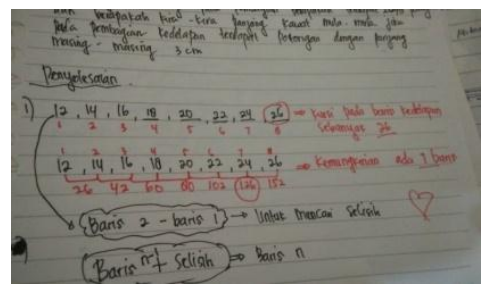

\section{Gambar 9 Hasil Jawaban Pretest Siswa}

Gambar 9 merupakan contoh dari proses hasil jawaban siswa yang sudah benar namun masih menyajikan satu cara penyelesaian saja.

Maka dapat disimpulkan bahwa proses hasil jawaban siswa pada penyelesaian soal pretesta di kelas eskperimen I maupun kelas eksperimen II jika disesuaikan dengan kriteria indikator kemampuan berpikir kreatif siswa masih rendah baik itu dalam

Jenny Vera Togatorop, Waminton Rajagukguk. Perbedaan Peningkatan Kemampuan Berpikir Kreatif Siswa yang Diajar dengan Pembelajaran Open Ended dan PBL di SMA Negeri 2 Kisaran. Jurnal Inspiratif, Vol. 4, No. 1 April 2018. 
indikator kelancaran, keluwesan, orisinal dan elaborasi

\section{b. Deskripsi Proses Hasil Jawaban Posttest Kemampuan Berpikir Kreatif Siswa}

Setelah diberikan pretest pada kedua kelas eksperimen, lalu dilakukan perlakuan pada masing-masing kelas eksperimen dengan model pembelajaran Open Ended untuk kelas eksperimen I dan model pembelajaran Berbasis Masalah untuk kelas eksperimen II maka diberikan posttest pada masing-masing kelas eskperimen untuk melihat apakah bagaimana peningkatan kemampuan berpikir kreatif siswa. Berikut deskriptif proses hasil jawaban posttest siswa :

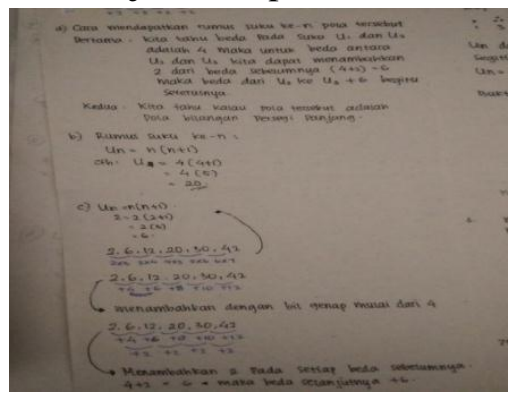

Gambar 10 Hasil Jawaban Posttest Siswa Kelas Eksperimen I

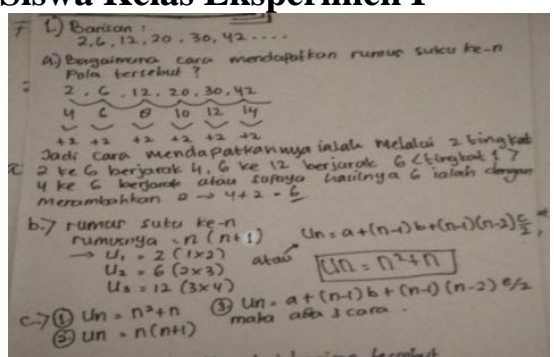

Gambar 11 Hasil Jawaban Posttest Siswa Kelas eksperimen II

Gambar 10 dan gambar 11 adalah contoh proses penyelesaian siswa dari masing-masing kelas eksperimen yang menginterpretasi bahwa sudah ditemukan siswa yang mampu menyelesaikan soal dengan benar bukan hanya dengan satu jawaban benar namun sudah lebih dari satu jawaban benar, sehingga indikator kelancaran sudah dipenuhi. Lalu jika dianalisis lebih lanjut bahwa proses hasil jawaban yang disajikan sudah menyajikan gagasan yang beragam maka dalam hal ini indikator keluwesan juga sudah dipenuhi.

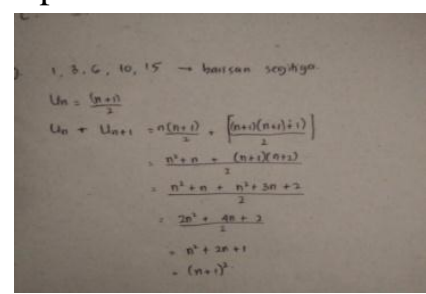

Gambar 12 Hasil Jawaban Posttest Siswa Kelas Eskperimen I

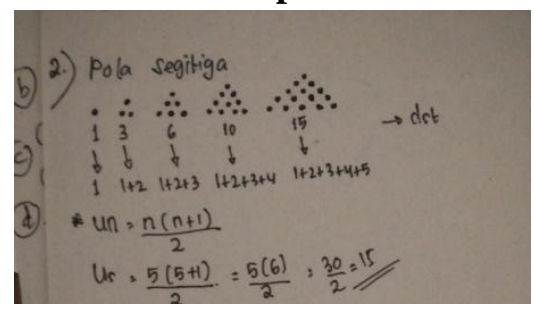

Gambar 13 Hasil Jawaban Posttest Siswa Kelas Eksperimen II

Gambar 12 dan gambar 13 merupakan contoh proses hasil jawaban siswa yang menginterpretasi bahwa dari masing-masing kelas sudah mampu memberikan jawaban yang berbeda dari yang lain nya atau jawaban yang orisinil dan benar. Sehingga untuk indikator orisinal dari kedua kelas eksperimen sudah dipenuhi.

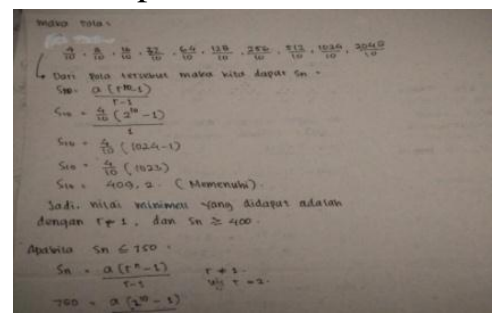

Gambar 14(a) Hasil Jawaban Posttest Siswa Kelas Eksperimen I

Jenny Vera Togatorop, Waminton Rajagukguk. Perbedaan Peningkatan Kemampuan Berpikir Kreatif Siswa yang Diajar dengan Pembelajaran Open Ended dan PBL di SMA Negeri 2 Kisaran. Jurnal Inspiratif, Vol. 4, No. 1 April 2018. 


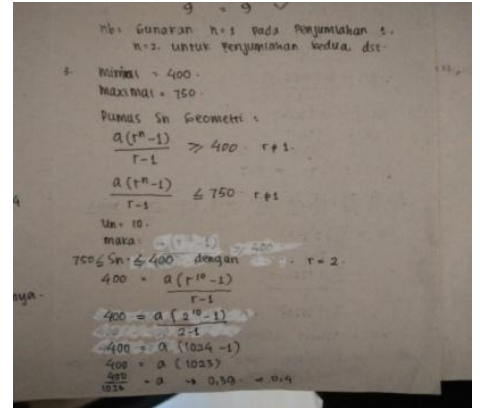

Gambar 14(b) Hasil Jawaban Posttest Siswa Kelas Eksperimen I

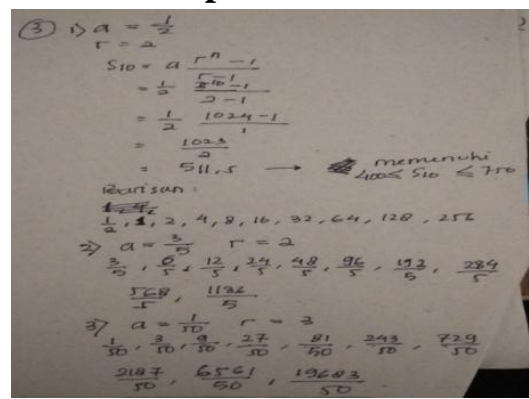

Gambar 15 Hasil Jawaban Posttest

\section{Siswa Kelas Eksperimen II}

Gambar 14 dan gambar 15 merupakan contoh proses hasil jawaban siswa yang sama-sama dapat memberikan lebih dari satu jawaban benar, dengan cara masing-masing benar, dengan gagasan yang beragam namun terdapat perbedaan pada penyajian cara yang disajikan. Terlihat bahwa cara yang disajikan pada kelas eksperimen I lebih mendetail atau lebih rinci dibandingkan dengan proses jawaban yang disajikan kelas eksperimen II sehingga untuk indikator elaborasi masih pada kelas eksperimen I yang ditemukan sudah memenuhi secara bersamaan ketika indikator kelancaran, keluwesan dan orisinal juga sudah dipenuhi.

Berdasarkan deskriptif dan analasis proses hasil jawaban posttest kemampuan berpikir kreatif siswa maka dapat disimpulkan bahwa pada masingmasing kelas eksperimen sudah memenuhi indikator kemampuan berpikir kreatif siswa. Jika ditinjau berdasarkan indikator, dari hasil analisis proses jawaban siswa maka dapat disimpulkan bahwa peningkatan paling tinggi pada indikator kemampuan berpikir kreatif siswa adalah pada indikator kelancaran karena secara umum sudah banyak ditemukan siswa yang dapat memberikan lebih dari 1 jawaban benar. Sedangkan peningkatan paling rendah pada indikator kemampuan berpikir kreatif siswa adalah pada indikator elaborasi karena secara umum masih sedikit siswa yang dapat memberikan jawaban benar dengan konsep dan cara yang mendetail.

\section{Pembahasan Hasil Penelitian}

Dalam penelitian ini digunakan dua model pembelajaran yaitu pembelajaran Open Ended dan pembelajaran Berbasis Masalah. Pembelajaran Open Ended dilaksanakan di kelas XII-IPA 1 sebagai kelas eksperimen I dan pembelajaran Berbasis Masalah dilaksanakan di kelas XII-IPA 3 sebagai kelas eksperimen II dengan masing-masing kelas terdiri dari banyak siswa yang sama yaitu terdiri dari 35 siswa.

Pembelajaran open ended dan pembelajaran berbasis masalah, keduanya merupakan pembelajaran yang menyajikan permasalahan. Bedanya, jika pada pembelajaran open ended merupakan pembelajaran yang menyajikan permasalahan dengan pemecahan berbagai cara ( flexibility) dan solusinya juga bisa beragam (multi jawaban, fluency) sedangkan pembelajaran berbasis masalah dalam konteks nyata kepada siswa. Jadi pembelajaran open ended merupakan modifikasi dari pembelajaran berbasis masalah. Kedua pembelajaran tersebut 
sama-sama untuk merangsang kemampuan berpikir tingkat tinggi siswa sehingga pada kedua pembelajaran tersebut melatih dan menumbuhkan orisinalitas ide, kreativitas, kognitif tinggi, kritis, komunikai-interaksi, sharing,keterbukaan dan sosialisasi. Sehingga siswa dituntut untuk berimprovisasi mengembangkan metode,cara,atau pendekatan yang bervariasi dalam memperoleh jawaban, selanjutnya siswa juga diminta untuk menjelaskan proses mencapai jawaban tersebut. Dengan demikian kedua pembelajaran ini lebih mementingkan prosess dari pada produk yang akan membentuk pola pikir keterpaduan, keterbukaan dan ragam berpikir. Selaras dengan apa yang menjadi indikator dalam penentuan berpikir kreatif seseorang.

Sebelum dilakukan pembelajaran pada masing-masing kelas, terlebih dahulu dilakukan pretes sebagai pembanding pada hasil posttest yang akan dilakukan setelah dilakukan pembelajaran. Dari hasil pretest nilai rata-rata pretest siswa kelas eksperimen I adalah 46,34 dan nilai rata-rata pretest kelas ekperimen II adalah 49,6. Berdasarkan nilai hasil pretest dilakukan pengujian normalitas dan homogenitas. Setelah dilakukan pengujian ternyata kedua kelas berdistribusi normal dan homogen. Lalu dilakukan pembelajaran Open Ended pada kelas eksperimen I dan pembelajaran Berbasis Masalah pada kelas eksperimen II. Setelah materi yang ditarget selesai semua diajarkan, siswa diberikan posttest sebagai pembanding dengan nilai hasil pretest kemampuan berpikir kreatif siswa pada kedua kelas. Dari hasil posttest nilai rata-rata posttest siswa kelas eksperimen I adalah 67,37 dan rata-rata posttest siswa kelas eksperimen II adalah 64,9. Dari hasil posttest masing-masing kelas eksperimen, dilakukan uji normalitas dan homogenitas lalu diperoleh bahwa hasil dari kedua kelas berdistribusi normal dan homogen.Kemudian untuk mengetahui peningkatan kemampuan berpikir kreatif siswa pada masingmasing kelas, dilakukan selisih tiap nilai posttest-pretest siswa pada masingmasing kelas dan diperoleh rata-rata selisih nilai posttest-pretest siswa pada kelas eksperimen I adalah 21,029 dan selisih nilai posttest-pretest siswa pada kelas eksperimen II adalah 14,886.dari hasil selisih posttest-pretest masingmasing kelas eksperimen dilakukan pengujian normalitas dan homogenitas lalu diperoleh bahwa selisih nilai posttest-pretest dari masing-masing kelas berdistribusi normal dan homogen. Berdasarkan rata-rata selisih nilai posttest-pretest kemampuan berpikir kreatif siswa dari masing-masing kelas bahwa rata-rata selisih nilai posttestpretest siswa pada kelas eksperimen I lebih tinggi dari bahwa rata-rata selisih nilai posttest-pretest siswa pada kelas eksperimen II yang berarti bahwa peningkatan kemampuan berpikir kreatif siswa yang diajarkan dengan model pembelajaran Open Ended lebih tinggi dari siswa yang diajarkan dengan model pembelajaran Berbasis Masalah.

Kemudian dilakukan pengujian hipotesis untuk peningkatan kemampuan berpikir kreatif siswa dari kedua kelas eksperimen. Setelah sebelumnya diperoleh nilai varians dari masingmasing kelas maka untuk pengujian hipotesis terlebih dahulu dicari nilai varian gabungan kedua kelas. Lalu setelah diperoleh nilai varian gabungan maka dicari nilai simpangan baku gabungan kedua kelas. Setelah itu

Jenny Vera Togatorop, Waminton Rajagukguk. Perbedaan Peningkatan Kemampuan Berpikir Kreatif Siswa yang Diajar dengan Pembelajaran Open Ended dan PBL di SMA Negeri 2 Kisaran. Jurnal Inspiratif, Vol. 4, No. 1 April 2018. 
langsung menggunakan rumus uji-t yang sesuai untuk data yang berdistribusi normal dan homogen sehingga diperoleh nilai $t_{\text {hitung }}=2,9168$. Maka setelah diperoleh nilai $t_{\text {hitung maka }}$ dibandingkan dengan nilai $t_{\text {tabel }}=$ 1,6676 yang diperoleh dari tabel uji-t dengan $\alpha=0,05$ dan $d k=n_{1}+n_{2}-$ $2=35+35-2=68$.

Karena $t_{\text {hitung }}=2,9168$ yang diperoleh tidak memenuhi $-t_{\text {tabel }}<t_{\text {hitung }}<t_{\text {tabel }}$ yang berarti $H_{0}$ ditolak dan $H_{a}$ diterima. Sehingga disimpulkan bahwa peningkatan kemampuan berpikir kreatif siswa yang diajar dengan pembelajaran Open Ended lebih tinggi dari peningkatan kemampuan berpikir

kreatif siswa yang diajar dengan pembelajaran Berbasis Masalah di SMA Negeri 2 Kisaran dengan perbedaan ratarata 6,1428 lebih tinggi. Hal tersebut disebabkan oleh penyajian soal pada LAS pembelajaran Open Ended lebih fleksibel, yang memungkinkan adanya jawaban lebih dari satu ataupun terdapat cara lebih dari 1 cara untuk mendapatkan jawaban benar sehingga lebih memicu kreatifitas siswa dalam menyelesaikan soal yang ada.

Proses hasil jawaban siswa juga di analisis baik itu proses hasil jawaban pretest siswa maupun proses hasil jawaban posttest siswa. Analisis dilakukan berdasarkan masing-masing indikator dari kemampuan berpikir kreatif siswa yaitu kelancaran, keluwesan, orisinal dan elaborasi. Dengan mendeskripsikan dan menganalisis hasil jawaban pretest siswa dapat disimpulkan bahwa untuk indikator kelancaran, keluwesan, orisinal dan elaborasi siswa masih belum terpenuhi atau masih rendah. Lalu setelah mendeskripsikan dan menganalisis hasil jawaban postest siswa dapat disimpulkan bahwa maasing-masing kelas sudah memenuhi indikator-indikator kemampuan berpikir kreatif siswa hanya saja bedanya bahwa pada kelas eksperimen I ditemukan siswa yang dapat menyelesaikan 1 soal dengan jawaban yang disajikan memenuhi ke-4 indikator dalam kemampuan berpikir kreatif siswa. Secara umum, indikator kemampuan berpikir kreatif siswa yang mengalami peningkatan paling tinggi adalah indikator kelancaran sedangkan indikator kemampuan berpikir kreatif siswa yang mengalami peningkatan paling rendah adalah indikator elaborasi pada pembelajaran Open Ended sedangkan pada pembelajaran Berbasis Masalah paling tinggi adalah indikator kelancaran dan yang paling rendah indikator orisinal. Selaras dengan penelitian yang relevan yang dilakukan oleh Firdaus, Abdur Rahman As'ari dan Abd. Qohar dalam penelitian mereka yang berjudul "Meningkatkan Kemampuan Berpikir Kreatif Matematis Siswa Sma Melalui Pembelajaran Open Ended Pada Materi SPLDV". Berdasarkan hasil penelitian tersebut bahwa pembelajaran dengan pendekatan open ended yang dapat meningkatkan kemampuan berpikir kreatif matematis siswa. Nenden Faridah, Isrok'atun, Ani Nur Aeni dalam penelitian mereka yang berjudul "Pendekatan Open-Ended Untuk Meningkatkan Kemampuan Berpikir Kreatif Matematis Dan Kepercayaan Diri Siswa". Berdasarkan hasil penelitian yang dilakukan, dapat disimpulkan bahwa peningkatan kemampuan berpikir kreatif matematis siswa dengan menggunakan pendekatan open-ended memiliki gain dengan kategori tinggi sebanyak 4 orang, gain

Jenny Vera Togatorop, Waminton Rajagukguk. Perbedaan Peningkatan Kemampuan Berpikir Kreatif Siswa yang Diajar dengan Pembelajaran Open Ended dan PBL di SMA Negeri 2 Kisaran. Jurnal Inspiratif, Vol. 4, No. 1 April 2018. 
dengan kategori sedang sebanyak 4 orang, dan gain dengan kategori rendah sebanyak 4 orang. Adapun rerata gainnya memiliki kategori sedang.Nova Nur Akmalia, Heni Pujiastuti, Yani Setiani (2016) dalam penelitianmereka yang berjudul "Identifikasi Tahap Berpikir Kreatif Matematis Melalui Penerapan Model Problem Based Learning Dengan Tugas Pengajuan Masalah". Berdasarkan penelitian tersebut disimpulkan bahwa dengan model Problem Based Learning dapat identifikasi setiap karakteristik dari kemampuan berpikir kreatif siswa dan dengan model pembelajaran tersebut dapat mendukung peningkatan kemampuan berpikir kreatif siswa. Ika Wahyu Anita (2017) dalam penelitiannya yang berjudul "Implementasi Pembelajaran Berbasis Proyek Untuk Menumbuhkan Kemampuan Berpikir Kreatif Matematis Mahasiswa”. Berdasarkan hasil penelitian dapat disimpulkan bahwa bahwa pembelajaran berbasis proyek dapat menumbuhkan kemampuan berpikir kreatif matematis mahasiswa dari siklus pertama hingga siklus kedua.

Yusliriadi,Darmawijoyo, Somakim dalam penelitian mereka yang berjudul "Pengembangan Soal Open-Ended Pokok Bahasan Barisan Dan Deret Bilangan Untuk Siswa SMP". Berdasarkan hasil penelitian mereka dapat disarankan kepada peneliti lain agar dapat mengembangkan soal openended untuk tingkat SD dan SMA sehingga dapat membantu guru untuk memperkaya variasi pemberian soal matematika dalam proses pembelajaran. Mohammad Amir (2017) dalam penelitiannya yang berjudul "Identifikasi Kesulitan Mahasiswa Dalam Memecahkan Masalah Open Ended Materi Nilai Mutlak". Berdasarkan penelitian tersebut dapat disimpulkan bahwa kesulitan mahasiswa ditemukan lebih bervariasi pada soal open ended, sehingga soal open ended dapat menjadi alternatif instrumen untuk mengevaluasi pendekatan suatu pembelajaran sehingga melalui metode open ended problem,siswa akan mendapat kesempatan untuk mengeksplorasi berbagai macam teknik penyelesaian. Rini Utami (2013) dalam peneltiannya yang berjudul "Model Pembelajaran Berbasis Masalah dengan Langkah Penyelesaian Berdasarkan Polya dan Krulik-Rudnick Ditinjau dari Kreativitas Siswa". Berdasarkan peneltiannya dapat disimpulkan bahwa model pembelajaran berbasis masalah dapat mempengaruhi kemampuan berpikir kreatif siswa.

\section{KESIMPULAN DAN SARAN}

Berdasarkan analisis hasil penelitian, maka dapat diperoleh kesimpulan dari hasil perhitungan uji hipotesis disimpulkan bahwa peningkatan kemampuan berpikir kreatif siswa yang diajar dengan pembelajaran Open Ended lebih tinggi dari peningkatan kemampuan berpikir kreatif siswa yang diajar dengan pembelajaran Berbasis Masalah di SMA Negeri 2 Kisaran dengan perbedaan rata-rata 6,1428 lebih tinggi dan setelah mendeskripsikan dan menganalisis proses hasil jawaban siswa maka dapat disimpulkan bahwa secara umum, indikator kemampuan berpikir kreatif siswa yang mengalami peningkatan paling tinggi adalah indikator kelancaran sedangkan indikator kemampuan berpikir kreatif siswa yang mengalami peningkatan paling rendah adalah indikator elaborasi.

$\begin{array}{rrr}\text { Hasil } & \text { penelitian } & \text { ini } \\ \text { kepada } & \text { peneliti }\end{array}$

Jenny Vera Togatorop, Waminton Rajagukguk. Perbedaan Peningkatan Kemampuan Berpikir Kreatif Siswa yang Diajar dengan Pembelajaran Open Ended dan PBL di SMA Negeri 2 Kisaran. Jurnal Inspiratif, Vol. 4, No. 1 April 2018. 
selanjutnya agar memberikan pengarahan kepada siswa untuk lebih teliti lagi dalam membaca soal, memahami apa yang dimaksud soal, memilih cara yang yang tepat untuk digunakan dalam menyelesaikan soal serta lebih teliti dalam melakukan perhitungan dan kepada guru khususnya guru matematika dapat menggunakan model pembelajaran Open Ended sebagai pembelajaran alternatif untuk meningkatkan kemampuan berpikir kreatif siswa.

\section{DAFTAR PUSTAKA}

Abdurrahman, M. 2009. Pendidikan Bagi Anak Berkesulitan Belajar. Jakarta: Rineka Cipta

Afgani, J. 2010. Pendekatan Open Ended dalam Pembelajaran Matematika. Bandung: FMIPA UPI.

Amir, M.A, (2017), Identifikasi Kesulitan Mahasiswa Dalam Memecahkan Masalah Open Ended Materi Nilai Mutlak, Jurnal Mercumatika, 2(2): 5565

Arikunto, S. 2006. Prosedur Penelitian Suatu Pendekatan Praktik.Jakarta:Bumi Aksara

Bell, G. 1991. Belajar dan Membelajarkan. Jakarta: CV.Rajawali

Bono, Edward de. 2007. Revolusi Berpikir.Bandung:PT. Mizan Pustaka

Daryanto. 2010. Media Pembelajaran

Peranannya Sangat

Penting Dalam Mencapai
Tujuan Pembelajaran.

Yogyakarta: Gava Media

Evans, James R. 1994. Berpikir

Kreatif. Jakarta : Bumi Aksara

Firdaus, Abdur Rahman As'ari dan

Abd.Qohar, (2016),

Meningkatkan Kemampuan

Berpikir Kreatif Matematis

Siswa SMA Melalui

Pembelajaran Open Ended

Pada Materi SPLDV, Jurnal

Ekonomi, 1(2):227-236

Green, Andy. 2000. Kreativitas dalam

Public Relations. Jakarta:

Erlangga

Hudojo, H. 2005. Pengembangan

Kurikulum dan

Pembelajaran Matematika.

Jakarta: UM Press

Ika, W.A (2017), Implementasi Pembelajaran

BerbasisProyek

UntukMenumbuhkan

Kemampuan Berpikir Kreatif

Matematis Mahasiswa, JPPM,

10(1): 125-131

Joyce, Bruce R.1992. Models of

Teaching. Amerika: Allyn and Bacon

Kunandar. 2011. Guru Profesional

Implementasi KTSP dan Sukses dalam Sertifikasi Guru. Jakarta: Raja Grafindo Prasada

Mahmudi, A. 2010. Mengukur

Kemampuan Berpikir Kreatif Matematis.Yogyakarta:UNY,

Makalah diajikan pada

Konfrensi Nasional

Matematika XV Unima

Manado

Manurung, T.W.H. dan Surya, E,

(2017), Penerapan Model

Jenny Vera Togatorop, Waminton Rajagukguk. Perbedaan Peningkatan Kemampuan Berpikir Kreatif Siswa yang Diajar dengan Pembelajaran Open Ended dan PBL di SMA Negeri 2 Kisaran. Jurnal Inspiratif, Vol. 4, No. 1 April 2018. 
Pembelajaran Creative Problem Solving Dalam Meningkatan Kemampaun Berpikir Kreatif Matematika Pada Siswa Sekolah Menengah Pertama (SMP) Al Hidayah Medan, Jurnal Mathematic Education.

Munandar. 1999. Pengembangan Kreativitas Anak Berbakat. Jakarta: Rineka Cipta

Novriani, M. R., Surya, E. 2017. Analysis of Student Difficulties in Mathematics Problem Solving Ability at MTs SWASTA IRA Medan, International Journal of Sciences Basic and Applied Research (IJSBAR), 33(3), 6375.

Nova Nur Akmalia, Heni Pujiastuti dan Yani Setiani, (2016), Identifikasi Tahap Berpikir Kreatif Matematis Melalui Penerapan Model Problem Based Learning Dengan Tugas Pengajuan Masalah, JPPM, 9(2): 183-193

Rini Utami, (2013), Model Pembelajaran Berbasis Masalah dengan Langkah Penyelesaian Berdasarkan Polya dan Krulik-Rudnick Ditinjau dari Kreativitas Siswa, Delta, 1(1): 87-103

Sagala. 2009. Evaluasi Hasil Belajar. Bandung : Remaja Rosdakarya Offset

Sanjaya ,H.Wina. 2011. Strategi Pembelajaran Berorientasi

Standar Proses

Pendidikan. Jakarta :

Kencana Prenada Media
Santrock, W. 2007. Psikologi Pendidikan. Jakarta: Prenada Media Group

Shadiq, F. 2004. Pemecahan Masalah Penalaran dan Komunikasi. Yogyakarta: Makalah Penataran PPG.

Sohimin, Aris. 2016. 68 Model Pembelajaran Inovatif dalam Kurikulum 2013. Yogyakarta : AR-RUZZ

MEDIA

Sudjana.2001. Metoda Statistika. Bandung : PT. Parsito

Sukmadinata ,Nana Syaodih. 2014. Metode Penelitian Pendidikan. Bandung: PT. Remaja Rosdakarya.

Surya, E., Sabandar, J. Kusumah, Y.S., Darhim. (2013). Improving of Junior High School Visual Thinking Representation Ability in Mathematical Problem Solving by CTL. IndoMS. J.M.E, Vol. 4 No. 1, pp. 113126.

Trianto. 2015. Mendesain Model Pembelajaran Inovatif Progresif. Jakarta : Kencana

Yusliriadi, Darmawijoyo dan Somakim, (2015), Pengembangan Soal Open

Ended Pokok Bahasan Barisan Dan Deret Bilangan Untuk Siswa SMP, Jurnal Elemen, 1(2):27-39

Jenny Vera Togatorop, Waminton Rajagukguk. Perbedaan Peningkatan Kemampuan Berpikir Kreatif Siswa yang Diajar dengan Pembelajaran Open Ended dan PBL di SMA Negeri 2 Kisaran. Jurnal Inspiratif, Vol. 4, No. 1 April 2018. 